\title{
Oncolytic Viruses: Priming Time for Cancer Immunotherapy
}

\author{
Luke Russell $^{1} \cdot$ Kah Whye Peng $^{1,2} \cdot$ Stephen J. Russell ${ }^{1,2} \cdot$ Rosa Maria Diaz $^{1}$
}

Published online: 18 July 2019

(c) The Author(s) 2019

\begin{abstract}
New immuno-oncology therapies are improving cancer treatments beyond the former standard of care, as evidenced by the recent and continuing clinical approvals for immunotherapies in a broad range of indications. However, a majority of patients (particularly those with immunologically cold tumors) still do not benefit, highlighting the need for rational combination approaches. Oncolytic viruses (OV) both directly kill tumor cells and inflame the tumor microenvironment. While OV spread can be limited by the generation of antiviral immune responses, the initial local tumor cell killing can reverse the immunosuppressive tumor microenvironment, resulting in more effective release of tumor-associated antigens (TAAs), cross-presentation, and antitumoral effector T cell recruitment. Moreover, many OVs can be engineered to express immunomodulatory genes. Rational combination approaches to cancer immunotherapy include the use of OVs in combination with immune checkpoint inhibitors (ICIs) or adoptive T cell therapy (ACT) to promote sustained antitumoral immune responses. OV combinations have additive or synergistic efficacy in preclinical tumor models with ICIs or ACT. Several preclinical studies have confirmed systemic reactivation and proliferation of adoptively transferred antitumoral $\mathrm{T}$ cells in conjunction with oncolytic OVs (expressing cytokines or TAAs) resulting from the specific tumor cell killing and immunostimulation of the tumor microenvironment which leads to increased tumor trafficking, activity, and survival. Recent clinical trials combining OVs with ICIs have shown additive effects in melanoma. Additional clinical data in an expanded range of patient indications are eagerly awaited. The relative timings of OV and ICI combination remains under-studied and is an area for continued exploration. Studies systematically exploring the effects of systemic ICIs prior to, concomitantly with, or following OV therapy will aid in the future design of clinical trials to enhance efficacy and increase patient response rates.
\end{abstract}

\section{Key Points}

Oncolytic viruses induce immunogenic tumor cell death, which makes them ideal partners for combination with immunotherapies such as immune checkpoint inhibitors and adoptive $\mathrm{T}$ cell therapies.

Effective combination therapies will depend on careful scheduling of the component parts.

Rosa Maria Diaz

rmdiaz@vyriad.com

1 Vyriad Inc., 3605 US Highway 52 N, Building 110, Rochester, MN 55901, USA

2 Department of Molecular Medicine, Mayo Clinic, Rochester, MN 55905, USA

\section{Oncolytic Virotherapy}

Oncolytic virotherapy is currently gaining traction as one of the most promising approaches for cancer immunotherapies in the clinical arena. Oncolytic viruses (OVs) have unique mechanisms of action compared to currently available treatments. Their antitumor effects include direct tumor-selective oncolysis, as well as activation of host systemic innate and adaptive immune responses [1,2] resulting in the recruitment of diverse immune cell types, including lymphocytes, into the tumor microenvironment. These qualities make OVs very attractive candidates for combination with cancer immunotherapies, which rely on the presence and function of antitumoral lymphocytic populations.

OVs are defined as replication competent viruses that selectively destroy tumor cells. Viruses have long been considered as possible antitumoral agents based on observations of cancer regressions after natural viral infections [3]. Tumors have evolved mechanisms of defective damage/pathogen recognition responses, making them more susceptible 
to viral infection. In addition, the ability to genetically engineer viral genomes has enabled the development of safe and powerful tumor-specific viruses that also express cytotoxic, immunomodulatory, or imaging genes. These agents can range from small RNA virus backbones, which encode only a handful of genes, often replicate quickly, and lyse tumor cells to release thousands of viral progeny, to large DNA virus backbones such as adenovirus, herpesvirus, or vaccinia virus, which can encode from 25 to over 250 different viral genes and allow more leeway for genetic manipulation but may be slower to replicate and spread [4-6].

The clinical safety of OVs is now being established, with thousands of patients treated to date using different virus platforms, doses, and routes of delivery. The majority of the OV clinical trials have tested intratumoral or local viral administrations with manageable safety profiles. Viruses that have been safely delivered intravenously into patients include adenovirus, measles virus, vaccinia virus, reovirus, picornavirus, and Newcastle disease virus. Most patients experience influenza-type symptoms within $24 \mathrm{~h}$ of administration and fluctuations in systemic cytokines levels a few hours after viral infusion that are usually readily manageable $[1,7]$.

The epidemiology of the parental virus, reflected in the seroprevalence of neutralizing antibodies to the viral vector, determines whether OVs can be delivered efficiently systemically or whether direct intratumoral injection is likely to be more effective. Direct intratumoral injection avoids the possibility of serum neutralization and provides efficient delivery. However, it also poses a technical challenge depending on the tumor location, which can require specialized injection techniques via interventional radiology. On the other hand, the treatment of disseminated tumors using a systemically delivered OV may provide a greater chance of virus infection of multiple tumor nodules, as each tumor does not need to be directly injected $[8,9]$. Clinical responses in further clinical studies testing different routes of administration and doses will determine optimal conditions for oncolytic virotherapy.

In 2015 the herpesvirus talimogene laherparepvec (T-VEC) was approved by the US Food and Drug Administration (FDA) for advanced melanoma and, as such, was the first OV to gain approval in the USA. In addition to its oncolytic effects, this virus encodes the granulocyte-macrophage colony-stimulation factor (GM-CSF) immunomodulatory gene for recruitment and activation of immune cells. When this virotherapy was administered intratumorally in melanoma patients, distant lesions that were not injected responded, indicating viral-mediated generation of a systemic immune response [10]. However, complete cures were not reported, indicating the need for combination therapies to achieve improved responses.
Therefore, in addition to direct tumor lysis, the importance of the immune response on the efficacy of OV therapy has been widely demonstrated [11-14]. Currently, most of the efforts to 'arm' OV consist of adding genes that have the ability to boost the activation of immune responses within the tumor microenvironment, such as cytokines or costimulatory molecules [15]. Following the approval of T-VEC, a large number of oncolytic virotherapy trials, using myriad viral platforms, have been initiated either as monotherapies or as combination therapies with other modalities, such as chemotherapy, radiotherapy and, in particular, immunotherapies $[16,17]$.

\section{Oncolytic Viruses (OVs) and Activation of Immune Responses}

Subsequent to viral infection, host cells orchestrate diverse mechanisms directed to shut down replication and avoid pathogenicity. Initially, viral pathogen-associated molecular patterns (PAMPs) are recognized by surface or intracellular host pattern recognition receptors (PRRs) followed by the activation of several signaling pathways, resulting in the induction of chemokines and cytokines such as type I interferons (IFNs). Therefore, activated innate immune cells, including neutrophils, granulocytes, natural killer (NK) cells, and antigen-presenting cells (APCs), will be the first to arrive and respond at the site(s) of infection. To consolidate pathogen control, an antiviral adaptive immune response produced by $\mathrm{B}$ and $\mathrm{T}$ cells is subsequently established $[17,18]$. Tumor cells and their microenvironment have evolved many mechanisms to suppress the generation of any local or systemic antitumoral immune effectors [19, 20]. Hence, OVs, due to their ability to selectively infect and replicate in tumor cells, as well as their capacity of attracting activated immune cells locally into the immunosuppressive tumor microenvironment, constitute an appealing strategy for cancer immunotherapy.

Different OVs kill tumor cells by triggering different cell death pathways with diverse degrees of immunogenicity. However, all of them will release PAMPs, which create an 'acute inflamed' environment consisting of activated de novo infiltrating and resident dendritic cells (DCs), macrophages, and NK cells, among others. These cells can destroy viralinfected tumor cells, release cytokines that can reduce tumor growth, and pick up viral and tumor antigens from dying tumor cells for presentation to, and activation of, $\mathrm{T}$ cells. However, at the same time, myeloid-derived suppressor cells (MDSCs) and regulatory T cells (Tregs) may also be recruited into the tumor microenvironment, serving to inhibit immune responses [17, 21]. OVs that can tilt the balance towards the generation of proinflammatory responses 
that cannot be counteracted by host/tumor immunosuppression would be appealing for further development.

\subsection{Innate Immune Responses}

The development of effective OVs for cancer immunotherapy relies on a comprehensive understanding of antiviral innate immune responses both in normal cells and tumor cells. Viral nucleic acids are detected by different types of PRRs. RNA viruses are recognized by retinoid acid-inducible receptors (retinoic acid-inducible gene 1 [RIG-1] and melanoma differentiation-associated protein 5 [MDA5]) and Toll-like receptor (TLF) 7 for single-stranded RNA or TLR3 for double-stranded RNA. DNA viruses are detected by cytosolic double-stranded DNA sensors including cyclic guanosine monophosphate-adenosine monophosphate synthase (cGAS) and IFN- $\gamma$ inducible protein 16 (IFI16), among others [22, 23].

Viruses trigger rapid antiviral innate immune responses that can compromise the replication/killing activity of OVs. Therefore, approaches have been developed to nullify such antiviral responses, including the use of the immunosuppressive drug cyclophosphamide or type I IFN inhibitors just before OV administration [24, 25], which will then enable further viral replication and subsequent tumor killing and priming of anti-tumor-associated antigen (TAA) T cell responses. In this way the balance is tipped towards extended viral replication and tumor cytotoxicity. For example, inhibition of IFN responses by oncolytic virotherapy in combination with dimethyl fumarate (FDA approved for the treatment of psoriasis and multiple sclerosis) has been shown to increase tumor viral spread and efficacy [26]. Combination of a herpesvirus expressing GM-CSF with the histone deacetylase inhibitor (HDACi) valproic acid resulted in augmented viral replication, oncolysis, and enhanced antitumor immunity [27]. Among the mechanisms of action of HDACis are transcriptional suppression of IFN-responsive genes, inhibition of viral clearance, and increased macrophage and CD8 T cell tumor infiltration [28, 29].

However, blocking the generation of strong antiviral innate responses will hamper the development of adaptive immune responses against both the virus and also against the tumor $[21,30]$. Ideally, the goal is to find the perfect balance between viral replication (cytotoxicity, innate triggering) and immune responses (replication restricting, tumor cell killing, adaptive $\mathrm{T}$ cell priming). Therefore, an ideal OV should accomplish the temporal tasks of replicating and killing tumor cells with subsequent release of tumor antigens in conjunction with PAMPs for the optimal generation of adaptive antitumoral immune responses. In this way, OVs can be considered as both cytotoxic and cancer vaccine agents. For example, OVs that induce type I IFNs by Stimulator of Interferon Genes (STING) signaling may have an advantage as this pathway has been shown to generate $\mathrm{T}$ cell immunity against dying tumor cells [31]. On the other hand, in the case of tumor cells with defective STING signaling, oncolytic therapy with herpes viruses was significantly improved due to enhanced tumor cell replication and cell-to-cell spread $[32,33]$. In addition, a recombinant attenuated oncolytic poliovirus, which infects APCs without killing them, generated sustained type I IFN activation leading to an inflammatory microenvironment permissive to the induction of enhanced adaptive immunity [12].

\subsection{Immunogenic Tumor Cell Death}

It has been shown that immunogenic cell death (ICD) is associated with potent cancer immunity. The hallmarks of ICD involve the release of specific damage-associated molecular patterns (DAMPs) from dying tumor cells: highmobility group box 1 (HMGB1), adenosine triphosphate (ATP), annexin 1, calreticulin, type I IFN, and tumor cellderived nucleic acids $[34,35]$. In vitro studies have shown that different OVs are capable of inducing tumor ICD, resulting in increased activation of antitumor innate responses and the ability of APCs to cross-present tumor antigens for effective priming of antitumoral human T cells [36-39]. Moreover, clinical data have shown that T-VEC-treated regressing melanoma tumors had an increased presence of antimelanoma-associated antigen-specific $\mathrm{T}$ cells [10]. It was also shown than oncolytic measles virus treatment in ovarian cancer patients augmented the endogenous $\mathrm{T}$ cell response against tumor antigens [40]. However, not all viruses are created equal. Therefore, it will be important to determine the capacity of different OVs to induce known or novel ICD markers that can exert a favorable impact on the effective development of antitumoral T cells. For example, many viruses express genes for blocking cell death pathways, which could reduce extensive ICD. Therefore, for OVs with poor ICD induction, an attractive option would be to incorporate ICD-related DAMP genes into their genomes for the potentiation of TAA visibility and immunogenicity during tumor infection. Another exciting option is the use of OVs armed with viral fusogenic membrane glycoproteins (FMGs). Surface tumor cell expression of FMGs will result in cell cytotoxicity by the generation of massive multinucleated giant cells (syncytia), which have been shown to induce ICD [41].

Tumor ICD should also occur in the presence of appropriately activated APCs that can both migrate to lymph nodes and present TAAs. The presence of conventional type 1 DCs (cDC1s) at tumor sites is associated with effective cancer immunity. In humans these are CD141+, C-type lectin domain-containing 9A+ $($ CLEC9A +$)$ cells that express the chemokine receptor $\mathrm{X}-\mathrm{C}$ motif chemokine receptor 1 (XCR1). Their presence in tumors has recently been associated with 
cancer patient survival [42-44]. Hence, it will be important to determine the ability of different OV to attract this subtype of DCs to the tumor. Additionally, OVs could be engineered to produce chemokines such as $\mathrm{X}-\mathrm{C}$ motif chemokine ligand 1 (XCL1), which is known to recruit cDC1s [44, 45]. An alternative approach currently in development is the OV-mediated local delivery of bispecific engager molecules directed against both tumor cells and $\mathrm{T}$ cells. This can result in the potent in situ activation of cytotoxic $\mathrm{T}$ cells without the need for APCs or major histocompatibility complex (MHC)-I/peptide expression [46, 47]. More recently, oncolytic adenoviruses expressing bispecific $\mathrm{T}$ cell engagers have shown to effectively target the immunosuppressive tumor stroma [48, 49].

On the other hand, OV 'in situ' vaccination produces antivirus $\mathrm{T}$ cell responses. These can be dominant over the responses to TAAs and to newly mutated tumor antigens (neoantigens), which are the most desirable. It then becomes a race between the generation of $\mathrm{T}$ cell responses against immune subdominant self TAA, more non-self neoantigens, and viral antigens. This problem could be overcome by modifying OVs to express TAAs if they are known [50-52]. Alternatively it is possible to delete nonessential OV genes, mutate immunodominant viral epitopes [6], or use prime-boosting regimens with different OVs. In this way, pre-existing anticancer $\mathrm{T}$ cells induced by the priming OVs will be specifically boosted after a second heterologous $\mathrm{OV}$ administration [53-55].

The generation of antiviral immune responses has long been considered detrimental for OV therapy. However, currently it is clear that the induction of effective systemic antitumoral responses rely on activation of innate immune cells [21]. Therefore, we hypothesize that an initial short inhibition of the innate responses by engineered $\mathrm{OV}$ would augment viral infection and tumor cell death with subsequent induction of enough 'heat' for adequate activation of immune innate cells, which are essential for effective adaptive $\mathrm{T}$ cell responses. For disseminated disease, it would be advantageous to use a systemic OV delivery. Several current clinical studies are focused on optimizing intravenous $\mathrm{OV}$ administration. For example, clinical systemic delivery of oncolytic reovirus was shown to generate the accumulation of cytotoxic $\mathrm{T}$ cells in brain metastases [14]. It would also be interesting to determine if the systemic innate immune response to the virus infusion could actually have any impact on tumor immunity and clinical responses.

\section{OVs and Immune Checkpoint Inhibitors}

\subsection{Immune Checkpoint Inhibition}

The immune system has developed a regulatory network to avoid excessive damage to the host after foreign insults.
The function of the adaptive immune system is controlled by sets of positive (immune co-stimulatory) and negative (immune inhibitory) regulators [56]. Tumor microenvironments evolve for dampening any antitumoral immune responses that could be generated in the course of tumor growth and dissemination. Hence, if present at all, antitumoral $\mathrm{T}$ cell effectors are inhibited by the upregulation of negative regulators in tumor, immune, endothelial, or stromal cells. This results in the presence of 'exhausted' $\mathrm{T}$ cells at the tumor site. Immune checkpoint inhibitor (ICI) therapy was designed to block the negative action of these regulators for efficient reactivation of exhausted $\mathrm{T}$ cell function and has proven to be a major breakthrough in cancer immunotherapy $[56,57]$.

ICIs have seen widespread clinical approvals in oncology. This includes the use of anti-cytotoxic T cell lymphocyte antigen 4 (CTLA4) antibodies and anti-programmed death 1 (PD1) receptor/ligand (PDL1) antibodies. CTLA4 is essential to limit rapid and uncontrolled $\mathrm{T}$ cell proliferation after priming of naïve $\mathrm{T}$ cells in secondary lymphoid organs, it diminishes $\mathrm{T}$ cell activation in peripheral tissues, and is also expressed on Treg cells. PD1, another co-inhibitory molecule found mainly on $\mathrm{T}$ cells, binds to PDL1 expressed on many types of cells and also binds to PDL2, which is specifically expressed on APCs. PDL1 has been shown to be overexpressed on tumor cells as an immune escape mechanism. Binding of PD1 with either ligand prevents activation of $\mathrm{T}$ cells and eventually leads to exhaustion. An increased activation of the immune system is generated by these antibodies by blocking $\mathrm{T}$ cell inhibitory signals that maintain $\mathrm{T}$ cell inactivity or exhaustion by cancer cells. It is thought that anti-CTLA4 antibodies work mainly at the initial stages of $\mathrm{T}$ cell priming and activation while PD1/PDL1 antibodies work mainly on exhausted T cells. However, PD1/PDL1 signals also have effects on antigen presentation by APCs, activated T cells, NK cells, and macrophages activities [56, 58].

Even though multiple malignancies now have an approved ICI therapy as part of the standard of care, these agents alone are unable to effectively control the cancers of a majority of treated patients $[59,60]$. As a result, exploration of new immuno-oncology combinations has increased in recent years. It has been demonstrated that low tumor mutational load and the lack of CD8 T cells in tumor areas (so-called 'cold tumors') are related to ICI therapy unresponsiveness $[61,62]$. In addition, targeting immunosuppressive myeloid cells with small molecules in the tumor microenvironment has resulted in the enhancement of ICI therapy [63]. Therefore, strategies aimed at altering the immunosuppressive tumor microenvironment and attracting new or pre-existing CD8 T cells to the tumor site (to turn the cold tumors hot) are being tested to increase favorable clinical responses to ICI therapy. 


\subsection{Combination Therapy in Preclinical Models}

Many OVs have been successfully combined with ICIs preclinically, resulting in enhanced tumor cell clearance and survival in murine tumor models [64-67]. More recently, OVs encoding immunostimulatory cytokines have also shown superiority when combined with ICIs. Combination of oncolytic vesicular stomatitis virus (VSV) expressing IFN- $\beta$ and a sodium iodide symporter reporter gene (VSV-IFN- $\beta$-NIS) with an anti-PDL1 antibody significantly inhibited progression of disseminated acute myeloid leukemia (AML) tumors compared to either treatment alone [68]. Oncolytic vaccinia virus expressing a membrane-bound interleukin (IL)-2 in combination with anti-PD1/PDL1 blockage also improved antitumor efficacy in a model of colon cancer. However, viral combination with anti-CTLA4 blockade did not have any enhanced effect [69]. Furthermore, a triple combination of an IL-12 expressing herpesvirus, anti-PD1, and anti-CTLA4 antibodies was required to enhance overall survival in a mouse model of glioblastoma [70].

Interestingly, neoadjuvant oncolytic virotherapy in combination with ICIs before surgery was recently reported to be successful in preventing tumor relapses in a model of murine breast cancer [71]. Of note, it has recently been shown that triple therapy of targeted MEK inhibition (trametinib; FDA approved for melanoma), T-VEC, and PD1 inhibition generated complete durable responses in murine models of melanoma and colorectal cancer. MEK inhibitors block mitogenactivated protein kinase kinase enzymes, which are often hyperactive in cancers. Trametinib inhibition was associated with decreased antiviral responses and increased CD8 $\mathrm{T}$ cells in the tumor microenvironment [72].

Different viruses, ICIs, doses, schedules, and tumor models will likely generate disparate results that can be difficult to compare when deciding which is the lucky combination therapy winner. As a note of caution, all these combination therapies in animal models rely only on the function of newly primed antitumor and antiviral $\mathrm{T}$ cells. In contrast, their effects on truly exhausted antitumor T cells, which exist in some patients, have not yet been fully elucidated [73]. A novel mouse model of glioblastoma can recapitulate 'truly exhausted' antitumoral T cells and could be a useful tool to evaluate the effects of ICI and OV combinations in preclinical models [74].

The timing of OV and ICI combination administration was evaluated using a vaccinia virus with either concurrent or delayed administration of an anti-CTLA4 antibody [75]. The study revealed that delayed administration improved overall survival of tumor-bearing mice, while concurrent administration did not. The authors concluded that the antiCTLA4 antibody could interfere with viral replication, thus reducing overall efficacy. In a separate study, CTLA4 inhibition was more effective shortly after vaccinia administration, while PD1 inhibition was more efficacious when delivered 7 days later [76]. Anti-CTLA4 antibody therapy was only effective when administered within 1 day of recombinant VSV administration in a murine breast cancer model [77]. A detailed listing of recent preclinical studies using different timing of combination OV and ICI therapy administration is shown in Table 1.

PDL1 is upregulated on many cells when stimulated by inflammatory cytokines, such as interferons generated by OVs. Therefore, viral infection of tumor cells will upregulate PDL1 expression that could then successfully be blockaded by ICI. Oncolytic reovirus has been shown to prime tumors for subsequent $\mathrm{PD}(\mathrm{L}) 1$ blockade in part through the upregulation of PDL1 on tumor cells following infection [78]. Similarly, T-VEC has been shown to have this effect in melanoma patients [79]. However, PDL1-negative tumors can also be responsive to anti-PD1/PDL1 antibodies, indicating that its expression on tumor cells is not always critical for responsiveness.

$\mathrm{OV}$-mediated local expression of ICIs from within infected tumor/surrounding cells is also currently under exploration. This could avoid toxicities that are often generated by the systemic administration of ICIs. Novel OVs engineered to express either full-length or single-chain variable fragment (scFv) anti-CTLA4 or anti-PDL1 antibodies have improved efficacy over parental virus in several preclinical murine tumor [80-82]. However, ICI expression would only be transient due to virus elimination by the immune system, which could be a problem for the generation of a sustainable immune response or extensive reactivation of exhausted lymphocytes. In addition, high local levels of ICIs in the tumor microenvironment could have completely unpredictable effects on other immune cells besides T cells, such as macrophages, MDSCs, or stroma cells, which could be immunosuppressive, immunostimulatory, or even toxic.

\subsection{Combination Therapy in Clinical Trials}

Because of the active immunostimulatory role of OVs in conferring de novo tumor immune cell infiltration, as well as encouraging combinatorial preclinical studies, over a third of the active OV trials listed on ClinicalTrials.gov are designed to explore the combination of OVs with ICI drugs. A recent clinical study of intratumoral administration of T-VEC in combination with pembrolizumab in patients with advanced melanoma indicated that $\mathrm{OV}$-induced tumor destruction creates a pro-inflammatory tumor microenvironment that promotes the influx of $\mathrm{T}$ cells, while local immunosuppressive signals can be blocked by ICIs to promote activation and amplification of antitumor $\mathrm{T}$ cell responses [79]. In addition, similar activity has been observed with the combination of a Coxsackievirus and ipilimumab or pembrolizumab $[83,84]$. These studies provide a clinical demonstration that 


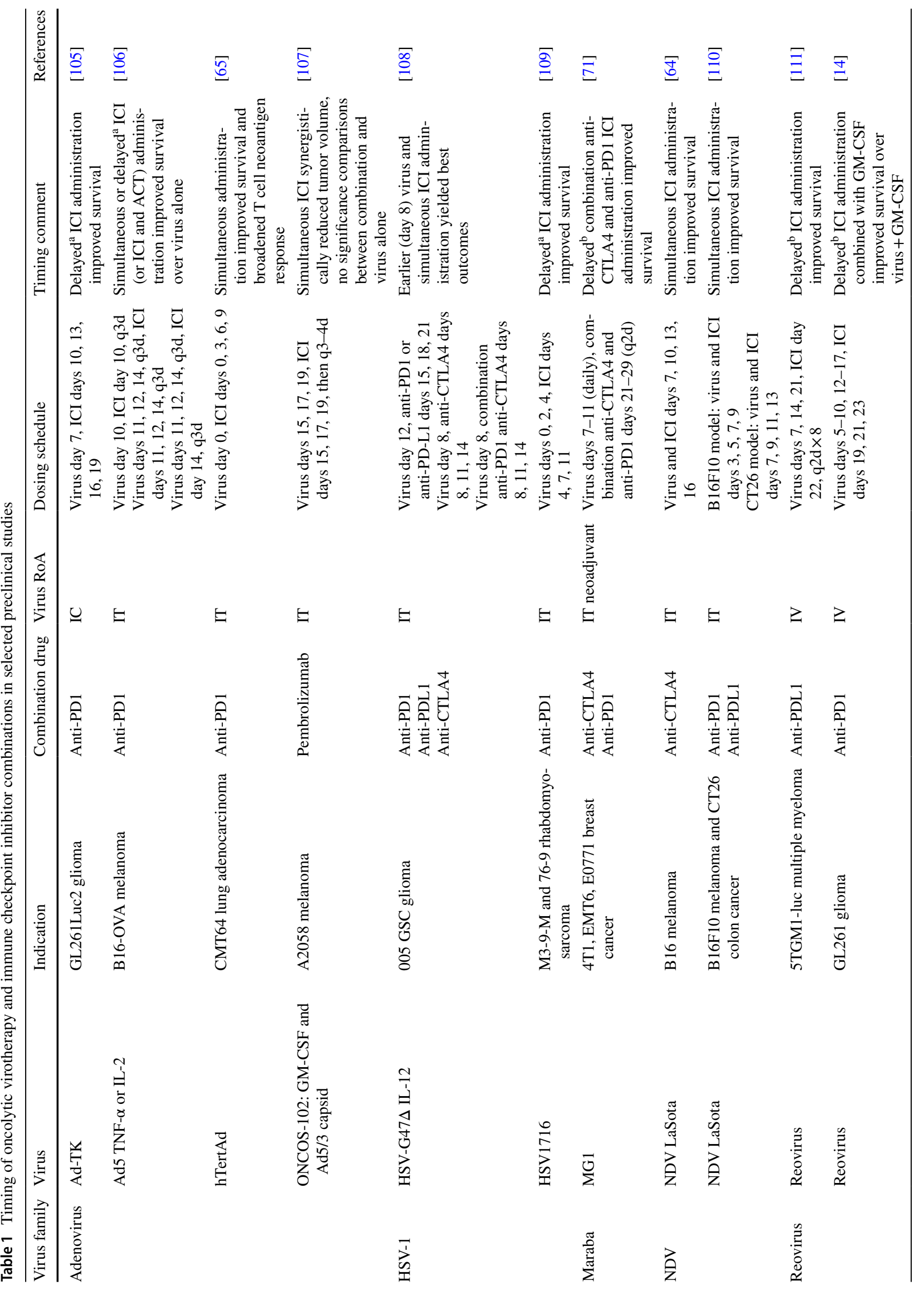




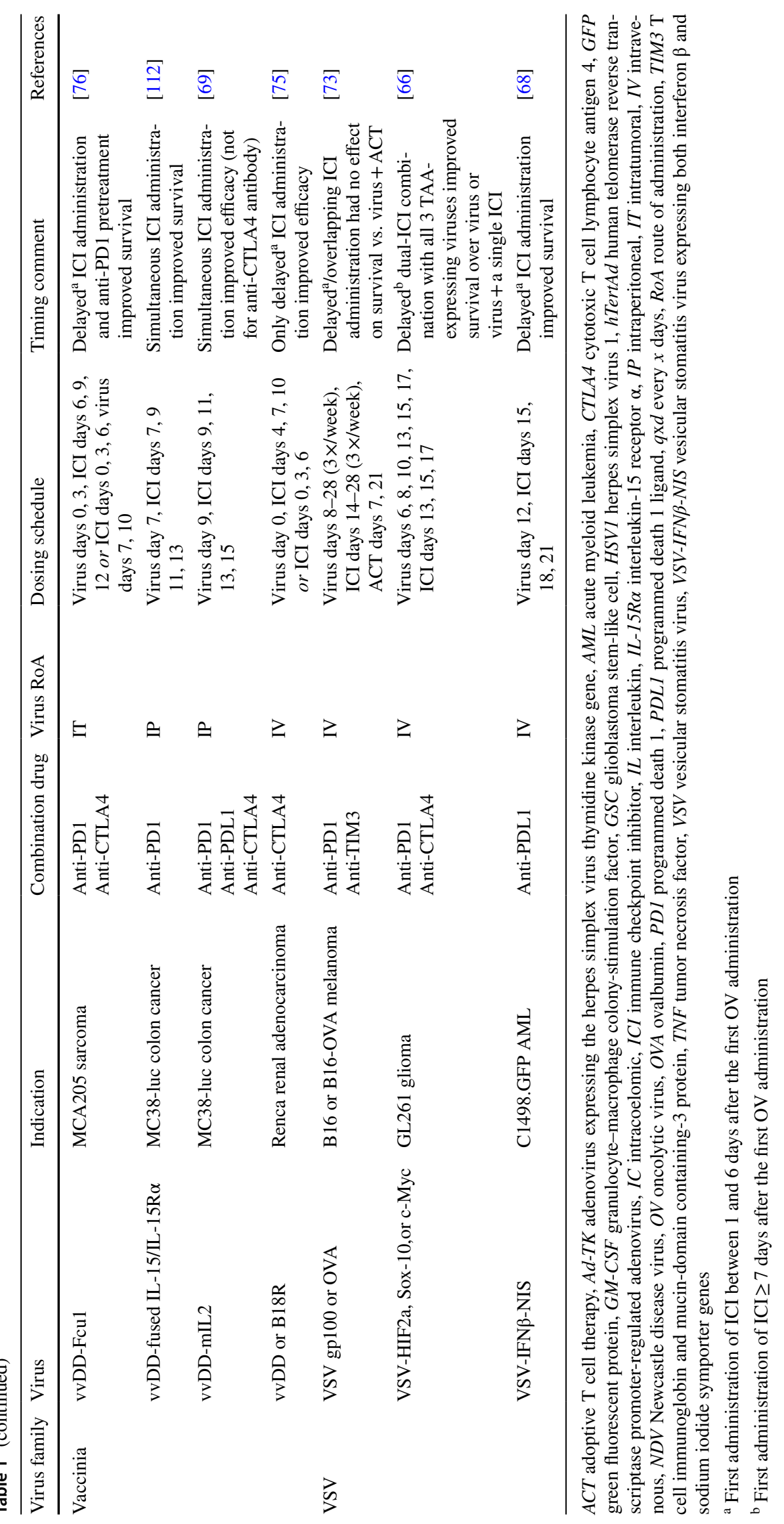


OV therapy can change the tumor microenvironment to promote $\mathrm{T}$ cell infiltration, potentially rendering a tumor more responsive to ICI therapy. Therefore, combination therapy with OVs and ICIs could enhance CD8+T cell infiltration and activation to improve therapeutic response in cancer patients who are previously or constitutively resistant to ICIs alone. However, the mechanisms behind each of these $\mathrm{T}$ cell inhibitory signaling pathways, and their effects on tumor regression, are not clearly understood. Therefore, a more complete mechanistic understanding of exactly how these antibodies work in the clinic is required to allow for development of effective and rational combination therapies [56].

Trial designs differ in the timing of OV versus ICI administration. Within the multitude of clinical combinations that are currently ongoing, a majority of trials combining OVs with anti-PD(L)1 or anti-CTLA4 antibodies coadminister virus and ICIs on day 1 . However, a few trials are exploring a staggered approach, initiating ICI administration at some point between day 8 (at 1 week) and day 43 (at 6 weeks) after virus administration (Table 2). For example, two studies are designed to test combination therapy with timing either 2 weeks pre-virus or 4 weeks post-virus in one study (ClinicalTrials.gov identifier NCT03773744), and either simultaneously, or starting 2 weeks after virus administration, in a second study (NCT03799744). Hopefully, results of the ongoing trials will reveal deeper mechanistic understandings of each virus and how they synergize with ICI, which will help in the future design of effective clinical trials.

Interestingly, it has recently been shown that CD28 costimulation is associated with successful PD1 inhibition and tumor regression [85], suggesting a benefit of simultaneously targeting co-stimulatory and inhibitory molecules. Indeed, several studies are currently testing the combination of antibodies targeting co-stimulatory pathways (CD40, 4-1BB, OX40) in combination with ICIs [86-88]. Therefore, it will be interesting to see if OVs can naturally induce, or can be modified to express, co-stimulatory signals in tumor cells or other immune cells when combined with ICI for the de novo generation of antitumoral $\mathrm{T}$ cells, or for the successful reinvigoration of pre-existing ones.

OVs are efficient agents for altering the tumor microenvironment, attracting activated new immune cells and reactivating existing ones. Oncolytic adenovirus in combination with ICIs was reported to broaden the repertoire of antineoantigen reactive $\mathrm{T}$ cells [65]. But, so far, OVs have not been shown to induce the expression of new neoantigens. Even though OVs show great promise when combined with ICIs, this may prove insufficient when dealing with low mutational burden cancers, which are largely refractory to ICI therapy. TAAs and tumor neoantigens are the currency for the induction of antitumoral responses and not even 'super-armed OV' combinations would be immunologically effective in their absence (although they may cause extensive oncolytic tumor destruction). Therefore, a major challenge for the OV field against these 'icy' tumors would be to demonstrate that they can promote the formation of neoepitopes. Targeted introduction of mutated TAAs/neoantigens within tumors or the delivery molecules that could activate transient mutagenesis mechanisms could be novel approaches to explore for the generation of highly inflamed responding tumors.

\section{OVs and Adoptive T Cell Therapies}

Adoptive T cell therapies (ACTs) involve the infusion of tumor-specific cytotoxic T cells into cancer patients. Pioneering studies in the 1980s demonstrated the presence of tumor-infiltrating lymphocytes (TILs) in melanoma patients. These cells could be expanded in culture supplemented with the cytokine IL-2, and when transferred back into patients conferred several objective clinical responses $[89,90]$. Complete and long-lasting clinical responses were achieved only with lymphodepletion protocols before ACT and with high doses of IL-2, resulting in high levels of toxicities [91-93]. Difficulties associated with isolating and expanding TILs from a variety of different cancer types has prevented widespread clinical implementation of this approach.

A major breakthrough in this field came with the ability to engineer and redirect autologous or allogeneic $\mathrm{T}$ cells specifically against cancer cells. Two types of antitumoral receptors can be introduced into T cells: TAA-specific $T$ cell receptors which are human leukocyte antigen (HLA) restricted, or chimeric antigen receptors (CARs) directed against tumor-specific proteins expressed on the surface of cancer cells. CARs consist of an extracellular tumor-targeted antibody fragment domain fused to a T cell receptor/ co-stimulatory signaling domain. ACT using CAR T cells has shown remarkable clinical success for leukemias and lymphomas, especially by targeting CD19 in B cells [94, 95]. However, the widespread application of CAR T cell therapy has been limited against solid tumors and currently this area represents an important clinical need. CAR T cells in clinical trials for solid tumors have been well-tolerated, but with patients only showing either partial responses or stable disease. Engineered CAR T lymphocytes must overcome the physical barriers imposed by solid tumor compartments. Efficient CAR T cell extravasation, specific tumor homing, cytotoxic activity, and persistence in a hostile tumor microenvironment are all necessary to increase the possibilities of success [96]. One attractive approach to surmount these barriers would be a combination therapy with OVs, whose tumor cell killing and immunostimulatory properties could result in increased CAR T cell tumor trafficking and activity. 
Table 2 Timing of oncolytic virotherapy and immune checkpoint inhibitor combinations in selected clinical trials

\begin{tabular}{|c|c|c|c|c|c|c|c|}
\hline Virus family & Virus & Indication & $\begin{array}{l}\text { Combination } \\
\text { drug }\end{array}$ & Virus RoA & Dosing schedule & Timing comment & $\begin{array}{l}\text { ClinicalTrials. } \\
\text { gov identifier }\end{array}$ \\
\hline \multirow[t]{5}{*}{ Adenovirus } & Ad-p53 & HNSCC & Nivolumab & IT & $\begin{array}{l}3 \times \text { virus (week } 1 \text { ), } \\
\text { nivolumab day } 5 \\
\text { Combination } \\
\text { repeats on week } \\
1 \text { of each cycle } \\
\text { q4w }\end{array}$ & $\begin{array}{l}\text { Delayed ICI } \\
\text { (4 days) }\end{array}$ & NCT03544723 \\
\hline & DNX-2401 & $\begin{array}{l}\text { GBM, gliosar- } \\
\text { coma }\end{array}$ & Pembrolizumab & IT & $\begin{array}{l}\text { Virus day } 1 \\
\text { Pembrolizumab } \\
\text { day } \sim 8, \mathrm{q} 3 \mathrm{w}\end{array}$ & $\begin{array}{l}\text { Delayed ICI } \\
\text { (1 week) }\end{array}$ & NCT02798406 \\
\hline & Enadenotucirev & $\begin{array}{l}\text { Advanced epithe- } \\
\text { lial tumors }\end{array}$ & Nivolumab & IV & $\begin{array}{l}\text { Unknown virus } \\
\text { schedule } \\
\text { Unknown } \\
\text { nivolumab } \\
\text { schedule }\end{array}$ & Unknown & NCT02636036 \\
\hline & ONCOS-102 & $\begin{array}{l}\text { Anti-PD1-refrac- } \\
\text { tory metastatic } \\
\text { melanoma }\end{array}$ & $\begin{array}{l}\text { Cyclophospha- } \\
\text { mide } \\
\text { Pembrolizumab }\end{array}$ & IT & $\begin{array}{l}\text { Cyclophosphamide } \\
\text { day }-1 \\
\text { Virus days } 1,4,8 \\
\text { Pembrolizumab } \\
\text { day 22, q3w }\end{array}$ & $\begin{array}{c}\text { Delayed ICI } \\
\text { (3 weeks) }\end{array}$ & NCT03003676 \\
\hline & VCN-01 & R/M HNSCC & Durvalumab & IV & $\begin{array}{l}\text { Arm 1: virus IV } \\
\text { day } 1 \text {, dur- } \\
\text { valumab IV day } \\
\text { 1, q4w } \\
\text { Arm } 2 \text { : virus IV } \\
\text { day } 1 \text {, dur- } \\
\text { valumab IV day } \\
15, \mathrm{q} 4 \mathrm{w}\end{array}$ & $\begin{array}{l}\text { Simultaneous ICI } \\
\text { or delayed ICI } \\
(2 \text { weeks })\end{array}$ & NCT03799744 \\
\hline \multirow[t]{3}{*}{ CVA21 } & Cavatak & $\begin{array}{l}\text { Uveal melanoma } \\
\text { with liver } \\
\text { metastases }\end{array}$ & Ipilimumab & IV & $\begin{array}{l}\text { Virus days } 1,3,8 \text {, } \\
\text { q3w (up to } 19 \times \text { ) } \\
\text { Ipilimumab day } 8 \text {, } \\
\text { q3w (up to } 4 \times \text { ) }\end{array}$ & $\begin{array}{l}\text { Delayed ICI } \\
\text { (1 week) }\end{array}$ & NCT03408587 \\
\hline & Cavatak & $\begin{array}{l}\text { Advanced mela- } \\
\text { noma }\end{array}$ & Pembrolizumab & IT & $\begin{array}{l}\text { Virus days } 1,3,8 \text {, } \\
\text { q3w (up to } 19 \times \text { ) } \\
\text { Pembrolizumab } \\
\text { day } 8, \mathrm{q} 3 \mathrm{w} \text { (up to } \\
2 \text { years) }\end{array}$ & $\begin{array}{l}\text { Delayed ICI } \\
\text { (1 week) }\end{array}$ & NCT02565992 \\
\hline & Cavatak & NSCLC & Pembrolizumab & IV & $\begin{array}{l}\text { Virus days } 1,3,8 \text {, } \\
\text { q3w (up to } 8 \times \text { ) } \\
\text { Pembrolizumab } \\
\text { q3w (up to } \\
24 \text { months) }\end{array}$ & Uncertain & NCT02824965 \\
\hline
\end{tabular}


Table 2 (continued)

\begin{tabular}{|c|c|c|c|c|c|c|c|}
\hline Virus family & Virus & Indication & $\begin{array}{l}\text { Combination } \\
\text { drug }\end{array}$ & Virus RoA & Dosing schedule & Timing comment & $\begin{array}{l}\text { ClinicalTrials. } \\
\text { gov identifier }\end{array}$ \\
\hline \multirow[t]{8}{*}{ HSV1 } & HF-10 & $\begin{array}{l}\text { Resectable } \\
\text { advanced mela- } \\
\text { noma }\end{array}$ & Nivolumab & IT neoadjuvant & $\begin{array}{l}9 \times \text { virus }(5 \times \text { virus } \\
\text { q1w then } \\
4 \times \text { virus } \mathrm{q} 2 \mathrm{w}) \\
\text { Nivolumab } \\
\mathrm{q} 2 \mathrm{w} \times 7 \text {, surgery, } \\
\text { nivolumab } \mathrm{q} 4 \mathrm{w} \\
\text { up to } 1 \text { year }\end{array}$ & Uncertain & NCT03259425 \\
\hline & T-VEC & $\begin{array}{l}\text { Early breast } \\
\text { cancer }\end{array}$ & Atezolizumab & Unknown & $\begin{array}{l}\text { Virus days } 1,21 \text {, } \\
\text { q2w } \\
\text { Atezolizumab day } \\
21, \mathrm{q} 2 \mathrm{w}\end{array}$ & Delayed ICI & NCT03802604 \\
\hline & T-VEC & $\begin{array}{c}\text { TNBC, CRC with } \\
\text { liver metastases }\end{array}$ & Atezolizumab & IT & $\begin{array}{l}\text { Virus day } 1, \mathrm{q} 3 \mathrm{w} \\
\text { Atezolizumab day } \\
1, \mathrm{q} 3 \mathrm{w}\end{array}$ & Simultaneous ICI & NCT03256344 \\
\hline & T-VEC & $\begin{array}{l}\text { Refractory lym- } \\
\text { phoma } \\
\text { Advanced or } \\
\text { refractory non- } \\
\text { melanoma skin } \\
\text { cancer }\end{array}$ & Nivolumab & IT & $\begin{array}{l}\text { Virus days } 1,21 \text {, } \\
\text { q2w } \\
\text { Nivolumab day } 21 \text {, } \\
\text { q2w }\end{array}$ & $\begin{array}{l}\text { Delayed ICI } \\
\text { (3 weeks) }\end{array}$ & NCT02978625 \\
\hline & T-VEC & $\begin{array}{l}\text { Malignant pleural } \\
\text { effusion }\end{array}$ & Nivolumab & Intrapleural & $\begin{array}{l}\text { Virus (unknown } \\
\text { schedule) } \pm \\
\text { nivolumab (same } \\
\text { day as virus) }\end{array}$ & Simultaneous ICI & NCT03597009 \\
\hline & T-VEC & $\begin{array}{l}\text { Advanced mela- } \\
\text { noma }\end{array}$ & Pembrolizumab & IT & $\begin{array}{l}\text { Virus day } 1, \mathrm{q} 3 \mathrm{w} \\
\text { Pembrolizumab } \\
\text { day } 1, \mathrm{q} 3 \mathrm{w}\end{array}$ & Simultaneous ICI & NCT02965716 \\
\hline & T-VEC & $\begin{array}{l}\text { Unresected mela- } \\
\text { noma }\end{array}$ & Pembrolizumab & IT & $\begin{array}{l}\text { Virus days } 1,21 \text {, } \\
\text { q2w } \\
\text { Pembrolizumab } \\
\text { week } 5, \mathrm{q} 3 \mathrm{w}\end{array}$ & $\begin{array}{l}\text { Delayed ICI } \\
\text { (5 weeks) }\end{array}$ & NCT02263508 \\
\hline & RP1 & $\begin{array}{l}\text { Melanoma, blad- } \\
\text { der, skin, MSI- } \\
\text { high solid }\end{array}$ & Nivolumab & IT & $\begin{array}{l}3 \times \text { virus in escalat- } \\
\text { ing doses q } 2 \mathrm{w} \\
\text { Unknown } \\
\text { nivolumab } \\
\text { schedule }\end{array}$ & Unknown & NCT03767348 \\
\hline \multirow[t]{2}{*}{ Maraba } & MG1-E6/E7 & $\begin{array}{l}\text { HPV-associated } \\
\text { cancer }\end{array}$ & $\begin{array}{l}\text { Ad-E6/E7 } \\
\text { Atezolizumab }\end{array}$ & IV or IT + IV & $\begin{array}{l}\text { Prime IM Ad-E6/ } \\
\text { E7 (-14 days) } \\
\text { 4×IV MG1-E6/ } \\
\text { E7 (spread over } \\
2 \text { weeks) OR IV } \\
\text { MG1-E6/E7 day } \\
\text { 1, IT MG1-E6/ } \\
\text { E7 days 4,14 } \\
\text { Atezolizumab day } \\
\text { 43, q3w }\end{array}$ & $\begin{array}{l}\text { Delayed ICI } \\
\text { (6 weeks) }\end{array}$ & NCT03618953 \\
\hline & MG1-MAGEA3 & $\begin{array}{c}\text { Metastatic mela- } \\
\text { noma, CSCC }\end{array}$ & $\begin{array}{l}\text { Ad-MAGEA3 } \\
\text { Pembrolizumab } \\
\text { Cyclophospha- } \\
\text { mide }\end{array}$ & IV or IT + IV & $\begin{array}{l}\text { Ad-MAGEA3 IM } \\
\text { day } 1 \pm \text { CPA day } \\
-3 \\
\text { Virus IV days } \\
15,18, \text { or IV day } \\
15, \text { IT days } 22, \\
29,36 \text { (+ day } 43, \\
\text { q3w IT boosters) } \\
\text { Pembrolizumab } \\
\text { q3w (start either } \\
\text { day } 1 \text { or week 6) }\end{array}$ & $\begin{array}{l}\text { Pre-virus ICI } \\
\text { (-2 weeks) or } \\
\text { delayed ICI } \\
\text { (4 weeks) }\end{array}$ & NCT03773744 \\
\hline
\end{tabular}


Table 2 (continued)

\begin{tabular}{|c|c|c|c|c|c|c|c|}
\hline Virus family & Virus & Indication & $\begin{array}{l}\text { Combination } \\
\text { drug }\end{array}$ & Virus RoA & Dosing schedule & Timing comment & $\begin{array}{l}\text { ClinicalTrials. } \\
\text { gov identifier }\end{array}$ \\
\hline \multirow[t]{2}{*}{ Reovirus } & Reolysin & $\begin{array}{l}\text { Advanced pan- } \\
\text { creatic adeno- } \\
\text { carcinoma }\end{array}$ & $\begin{array}{l}\text { Chemotherapy } \\
\text { Pembrolizumab }\end{array}$ & IV & $\begin{array}{l}\text { Virus days } 1,2 \\
\mathrm{q} 3 \mathrm{w} \\
\text { Chemotherapy } \\
\text { combination day } \\
1 \mathrm{q} 3 \mathrm{w} \\
\text { Pembrolizumab } \\
\text { day } 8 \mathrm{q} 3 \mathrm{w}\end{array}$ & $\begin{array}{l}\text { Delayed ICI } \\
\text { (1 week) }\end{array}$ & NCT02620423 \\
\hline & Reolysin & $\begin{array}{l}\text { Advanced pan- } \\
\text { creatic cancer }\end{array}$ & Pembrolizumab & IV & $\begin{array}{l}\text { Virus days } 1,2 \text {, } \\
3,8+\text { days } 1, \\
8 \mathrm{q} 3 \mathrm{w} \text { (up to } \\
24 \text { months) } \\
\text { Pembrolizumab } \\
\text { day } 1, \mathrm{q} 3 \mathrm{w}\end{array}$ & Simultaneous ICI & NCT03723915 \\
\hline \multirow[t]{4}{*}{ Vaccinia } & PexaVec & $\begin{array}{l}\text { Unresectable } \\
\text { RCC }\end{array}$ & Cemiplimab & IV or IT & $\begin{array}{l}3 \times \text { virus IT q2w or } \\
4 \times \text { virus IV q1w, } \\
\text { cemiplimab q3w } \\
\text { Cemiplimab q3w: } \\
\text { @ PD, } 3 \times \text { virus } \\
\text { IT q2w }\end{array}$ & Uncertain & NCT03294083 \\
\hline & PexaVec & Refractory CRC & $\begin{array}{l}\text { Durvaumab } \\
\text { Tremelimumab }\end{array}$ & IV & $\begin{array}{l}\text { Virus days } 2,12 \text {, } \\
16 \text { cycle } 1 \text {, day } 2 \\
\text { cycle } 2 \\
\text { Durvalumab day } 1 \\
\text { each cycle } \\
\text { Tremelimumab day } \\
1 \text { cycles } 1-4\end{array}$ & Simultaneous ICI & NCT03206073 \\
\hline & PexaVec & $\begin{array}{l}\text { Advanced solid } \\
\text { tumors }\end{array}$ & Ipilimumab & IT & $\begin{array}{l}\text { Virus up to } \\
5 \times(\text { weeks } 1,3 \text {, } \\
5,9,+ \text { week } 12 \\
\text { if PD) } \\
\text { Ipilimumab up to } \\
4 \times \text { IT (weeks } 3 \text {, } \\
5,9,+ \text { week } 12 \\
\text { if PD) }\end{array}$ & $\begin{array}{l}\text { Delayed ICI } \\
\text { (3 weeks) }\end{array}$ & NCT02977156 \\
\hline & PexaVec & $\mathrm{HCC}$ & Nivolumab & IT & $\begin{array}{l}\text { Virus days } 1,15 \text {, } \\
29 \\
\text { Nivolumab day } 15 \\
\text { q2w }\end{array}$ & $\begin{array}{c}\text { Delayed ICI } \\
\text { (2 weeks) }\end{array}$ & NCT03071094 \\
\hline \multirow[t]{2}{*}{ VSV } & VSV-IFN $\beta$-NIS & Solid Tumors & Avelumab & IV & $\begin{array}{l}\text { Virus day } 1 \text {, } \\
\text { avelumab day } 1 \text {, } \\
\text { q3w }\end{array}$ & Simultaneous ICI & NCT02923466 \\
\hline & VSV-IFN $\beta$-NIS & HNSCC, NSCLC & Pembrolizumab & IV & $\begin{array}{l}\text { Virus day } 1, \text { pem- } \\
\text { brolizumab day } \\
\text { 1, q3w }\end{array}$ & Simultaneous ICI & NCT03647163 \\
\hline
\end{tabular}

CPA cyclophosphamide, $C R C$ colorectal cancer, CSCC cutaneous squamous cell carcinoma, CVA21 coxsackievirus A21, GBM glioblastoma, $H C C$ hepatocellular carcinoma, HNSCC head and neck squamous cell carcinoma, HPV human papillomavirus, $H S V 1$ herpes simplex virus $1, I C I$ immune checkpoint inhibitor, $I M$ intramuscular, $I T$ intratumoral, $I V$ intravenous, MAGEA3 melanoma-associated antigen 3, MSI microsatellite instability, NSCLC non-small cell lung carcinoma, $P D$ progressive disease, $P D 1$ programmed death $1, q \times w$ every $x$ weeks, $R C C$ renal cell carcinoma, $R / M$ recurrent/metastatic, RoA route of administration, TNBC triple-negative breast cancer, $T$-VEC talimogene laherparepvec, $V S V$-IFN $\beta$ $N I S$ vesicular stomatitis virus expressing both interferon $\beta$ and sodium iodide symporter genes

In this respect, several preclinical studies have demonstrated the feasibility of this approach [97]. More recently, it has been shown in a syngeneic mouse model of pancreatic cancer that combined therapy of anti-mesothelin CAR T cells with an oncolytic adenovirus expressing the cytokines tumor necrosis factor (TNF)- $\alpha$ and IL-2 significantly improved tumor eradication. Effective therapy was related to an increased intratumoral accumulation of both CARs and host CD8 and CD4 T cells and an altered tumor microenvironment with $\mathrm{M} 1$ polarization of macrophages and increased DC maturation [98]. More studies in immunocompetent mouse models are required 
to determine the role of antiviral immunity on the antitumoral function of the transferred CAR T cells and the toxicities associated with the combination therapy. Interestingly, it has also been reported that local treatment with an oncolytic adenovirus along with two adenoviral vectors, one expressing IL-12 and the other an anti-PDL1 antibody, in combination with systemic administration of anti-human epidermal growth factor receptor 2 (HER2) CAR $T$ cells augmented therapy against both primary and metastasized tumors in a xenograft model of head and neck cancer [82]. Future studies will determine if triple combinations of armed OVs, ACTs, and ICIs could be even more effective than double combinations in cancer immunotherapy.

Adoptive transfer of naïve, TAA-specific murine T cells, in combination with VSV-expressed cognate TAAs, generates potent antitumor activity in models of both local and metastatic disease in a murine model of melanoma. This effect could not be replicated with the transfer of pre-activated cytotoxic T cells. The increased ability of VSV-TAA compared with a control vesicular stomatitis virus (VSV)-green fluorescent protein (GFP), to activate naive $\mathrm{T}$ cells in vivo, was due primarily to presentation of virus-expressed TAAs by lymph node-resident APCs, themselves activated by the presence of immunogenic virus particles and proteins [30, 99]. The fact that established tumors can be eradicated with this highly potent combination was confirmed by other studies in which 'oncolytic vaccines' based on vaccinia virus, or VSV, expressing TAAs drove rapid expansion and tumor infiltration of transferred TAA-specific central memory T cells [100]. Therefore, different from other approaches in which OVs encode cytokines, in this combination therapy OV-TAA is associated with highly inflammatory in vivo presentation of the TAAs to the transferred T cells, leading to highly efficient in vivo activation and expansion. Moreover, efficacy in these studies was not dependent on prior lymphodepletion, irradiation, or exogenous IL-2 administration.

Classical adoptive $\mathrm{T}$ cell transfer protocols utilize terminally differentiated effector $T$ cells that have been cultured in vitro with IL-2 for several weeks and are therefore shortlived. Current evidence suggests that less differentiated cells, such as central memory $\mathrm{T}$ cells or stem-like memory $\mathrm{T}$ cells, show superior efficacy $[101,102]$. In combination with OV-TAA, naïve or less differentiated $\mathrm{T}$ cells responded very quickly and effectively to priming or antigen re-exposure by proliferating and activating effector functions. Thus, by combining OV-TAA with ACTs of poorly differentiated phenotypes it should be possible to minimize the number of memory $\mathrm{T}$ cells that must be transferred into patients to avoid extensive in vitro culture protocols.

Because it has been shown preclinically that the combination of OVs expressing TAAs along with ACTs targeted against the same antigen is superior to either treatment alone, the development of future clinical trials with this type of combination therapy is warranted in the near future.

\section{Concluding Remarks}

Clinical use of immunotherapies as anticancer agents has grown rapidly in the last decade, highlighted by numerous approvals for ICIs and CAR T cells. The regulatory approval of T-VEC by the FDA for patients with advanced melanoma was a watershed moment for the field of oncolytic virotherapy. It remains to be seen how the direct oncolytic properties of different OVs can generate diverse levels and potencies of tumor-specific immunity. Furthermore, even though viral spread can be limited by the generation of antiviral immune responses, the initial local tumor cell killing can reverse the immunosuppressive tumor microenvironment, resulting in more effective TAA presentation and effector $\mathrm{T}$ cell recruitment [21].

Rational combination approaches to cancer immunotherapy include the use of OVs to inflame the tumor and recruit a variety of immune cells to the tumor microenvironment through inflammatory viral oncolysis in combination with ICI or ACT therapies to promote sustained antitumoral immune responses [103, 104] (Fig. 1). OV combinations have additive or synergistic efficacy in preclinical tumor models with ICIs or ACTs, and recent clinical trials combining OVs with ICIs show additive effects in melanoma. However, additional clinical data in an expanded range of patient indications are required in this area. The relative timing(s) of the administration of anti-CTLA4, OVs, anti-PD(L)1, and emerging ICI antibodies is an area that requires intensive scrutiny. Studies systematically exploring the effects of systemic ICIs prior to, concomitantly with, or following OV therapy will aid in the future design of clinical trials to enhance efficacy and drive up patient response rates.

Several preclinical studies now have confirmed systemic reactivation and proliferation of adoptively transferred antitumoral T cells in conjunction with oncolytic OVs (expressing cytokines or TAAs) whose specific tumor cell killing and immunostimulatory properties altered the tumor microenvironment resulting in increased $\mathrm{T}$ cell tumor trafficking, activity, and survival.

To date, the majority of OV clinical trials have been focused on viral attenuation and modes of delivery for testing their safety profile as monotherapies or in combination with other modalities. The ability to genetically engineer different $\mathrm{OV}$ s for the inclusion of different immunomodulatory genes to tip the balance towards antitumoral immune responses, coupled with an increasing knowledge of their management in the clinic, offer exciting times in this area of cancer research. More preclinical studies, smart clinical trial designs, and correlative studies 


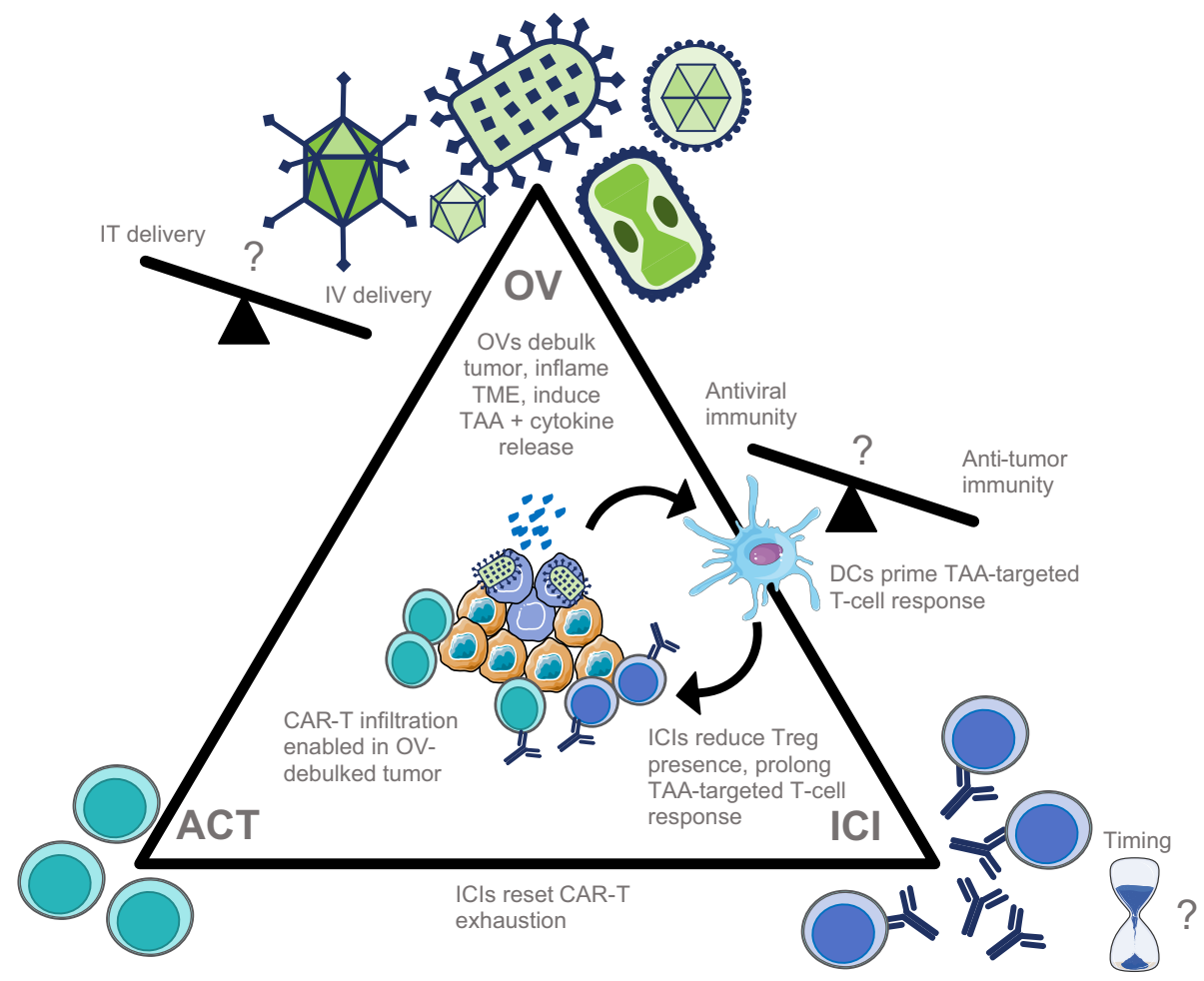

Fig. 1 Prime timing for oncolytic viruses (OVs). The myriad of possible interactions of OVs, immune checkpoint inhibitors (ICIs), and adoptive $\mathrm{T}$ cell therapy (ACT) for cancer immunotherapy. OVs debulk solid tumors, promote strong antiviral innate responses, and inflame the tumor microenvironment (TME). OVs also prime the adaptive immune response by the release of tumor-associated antigens (TAAs) from lysed tumor cells, allowing dendritic cells (DCs) to prime anti-TAA $T$ cells which can now infiltrate the tumor. ICIs can assist with anti-TAA $\mathrm{T}$ cell priming, prevent $\mathrm{T}$ cell exhaustion, and reinvigorate exhausted $\mathrm{T}$ cell function when it arises. ACT effec-

determining the requirements and specific mechanisms by which OVs prime effective antitumoral $\mathrm{T}$ cell responses are now necessary. It seems highly likely that these antitumor immunity priming OV are now ready to be allocated a primetime slot in cancer immunotherapy, either as solo artists or in combination with their fellow stars such as checkpoint inhibitors and ACTs. Stay tuned!

\section{Compliance with Ethical Standards}

Funding No external funding was used in the generation of this review.

Conflict of interest L Russell and R.M. Diaz are employees of and own stock/options in Vyriad. K.W. Peng and S.J. Russell own stock/options in Vyriad and are inventors of patents licensed from Mayo Clinic to Vyriad relating to oncolytic measles and vesicular stomatitis virus technology. tor cells ( $\mathrm{T}$ cell receptor $\mathrm{T}$ cells [TCR-T], chimeric antigen receptor $\mathrm{T}$ cells [CAR-T], chimeric antigen receptor natural killer cells [CAR$\mathrm{NK}$, or others) remain susceptible to the immunosuppressive milieu in solid tumors as well as exhaustion, which can be reversed using OVs and ICIs, respectively. Elucidation of the mechanistic basis underpinning the combinatorial interactions of OVs, ICIs, and ACT will help to determine the precise scheduling of each component required to achieve optimal efficacy. $I T$ intratumoral, $I V$ intravenous, Treg regulatory $\mathrm{T}$ cells

Open Access This article is distributed under the terms of the Creative Commons Attribution-NonCommercial 4.0 International License (http://creativecommons.org/licenses/by-nc/4.0/), which permits any noncommercial use, distribution, and reproduction in any medium, provided you give appropriate credit to the original author(s) and the source, provide a link to the Creative Commons license, and indicate if changes were made.

\section{References}

1. Lawler SE, Speranza MC, Cho CF, Chiocca EA. Oncolytic viruses in cancer treatment: a review. JAMA Oncol. 2017;3(6):841-9.

2. Raja J, Ludwig JM, Gettinger SN, Schalper KA, Kim HS. Oncolytic virus immunotherapy: future prospects for oncology. $\mathrm{J}$ Immunother Cancer. 2018;6(1):140. 
3. Kelly E, Russell SJ. History of oncolytic viruses: genesis to genetic engineering. Mol Ther. 2007;15(4):651-9.

4. Fountzilas C, Patel S, Mahalingam D. Review: oncolytic virotherapy, updates and future directions. Oncotarget. 2017;8(60):102617-39.

5. Russell SJ, Peng KW. Oncolytic virotherapy: a contest between apples and oranges. Mol Ther. 2017;25(5):1107-16.

6. Howells A, Marelli G, Lemoine NR, Wang Y. Oncolytic viruses-interaction of virus and tumor cells in the battle to eliminate cancer. Front Oncol. 2017;7:195.

7. Machiels JP, Salazar R, Rottey S, Duran I, Dirix L, Geboes K, et al. A phase 1 dose escalation study of the oncolytic adenovirus enadenotucirev, administered intravenously to patients with epithelial solid tumors (EVOLVE). J Immunother Cancer. 2019;7(1):20

8. Breitbach CJ, De Silva NS, Falls TJ, Aladl U, Evgin L, Paterson $\mathrm{J}$, et al. Targeting tumor vasculature with an oncolytic virus. Mol Ther. 2011;19(5):886-94.

9. Garcia-Carbonero R, Salazar R, Duran I, Osman-Garcia I, PazAres L, Bozada JM, et al. Phase 1 study of intravenous administration of the chimeric adenovirus enadenotucirev in patients undergoing primary tumor resection. J Immunother Cancer. 2017;5(1):71.

10. Kaufman HL, Kim DW, DeRaffele G, Mitcham J, Coffin RS, Kim-Schulze S. Local and distant immunity induced by intralesional vaccination with an oncolytic herpes virus encoding GMCSF in patients with stage IIIc and IV melanoma. Ann Surg Onc. 2010;17(3):718-30.

11. Guo ZS, Liu Z, Kowalsky S, Feist M, Kalinski P, Lu B, et al. Oncolytic immunotherapy: conceptual evolution, current strategies, and future perspectives. Front Immunol. 2017;8:555.

12. Brown MC, Holl EK, Boczkowski D, Dobrikova E, Mosaheb $\mathrm{M}$, Chandramohan V, et al. Cancer immunotherapy with recombinant poliovirus induces IFN-dominant activation of dendritic cells and tumor antigen-specific CTLs. Sci Transl Med. 2017;9(408):eaan4220.

13. Yin J, Markert JM, Leavenworth JW. Modulation of the intratumoral immune landscape by oncolytic herpes simplex virus virotherapy. Front Oncol. 2017;7:136.

14. Samson A, Scott KJ, Taggart D, West EJ, Wilson E, Nuovo GJ, et al. Intravenous delivery of oncolytic reovirus to brain tumor patients immunologically primes for subsequent checkpoint blockade. Sci Transl Med. 2018. https://doi.org/10.1126/scitr anslmed.aam7577.

15. de Graaf JF, de Vor L, Fouchier RAM, van den Hoogen BG. Armed oncolytic viruses: a kick-start for anti-tumor immunity. Cyto Growth Factor Rev. 2018;41:28-39.

16. Chen CY, Hutzen B, Wedekind MF, Cripe TP. Oncolytic virus and PD-1/PD-L1 blockade combination therapy. Oncolytic Virother. 2018;7:65-77.

17. van Vloten JP, Workenhe ST, Wootton SK, Mossman KL, Bridle BW. Critical interactions between immunogenic cancer cell death, oncolytic viruses, and the immune system define the rational design of combination immunotherapies. J Immunol. 2018;200(2):450-8.

18. Melchjorsen J. Learning from the messengers: innate sensing of viruses and cytokine regulation of immunity - clues for treatments and vaccines. Viruses. 2013;5(2):470-527.

19. Vinay DS, Ryan EP, Pawelec G, Talib WH, Stagg J, Elkord E, et al. Immune evasion in cancer: mechanistic basis and therapeutic strategies. Semin Cancer Biol. 2015;35(Suppl):S185-98.

20. Gajewski TF, Schreiber H, Fu YX. Innate and adaptive immune cells in the tumor microenvironment. Nat Immunol. 2013;14(10):1014-22.

21. Gujar S, Pol JG, Kim Y, Lee PW, Kroemer G. Antitumor benefits of antiviral immunity: an underappreciated aspect of oncolytic virotherapies. Trends Immunol. 2018;39(3):209-21.
22. Lee J, Ghonime MG, Wang R, Cassady KA. The antiviral apparatus: STING and oncolytic virus restriction. Mol Ther Oncolytics. 2019;28(13):7-13.

23. Bommareddy PK, Shettigar M, Kaufman HL. Integrating oncolytic viruses in combination cancer immunotherapy. Nat Rev Immunol. 2018;18(8):498-513.

24. Fulci G, Breymann L, Gianni D, Kurozomi K, Rhee SS, Yu $\mathrm{J}$, et al. Cyclophosphamide enhances glioma virotherapy by inhibiting innate immune responses. Proc Natl Acad Sci USA. 2006;103(34):12873-8.

25. Maroun J, Munoz-Alia M, Ammayappan A, Schulze A, Peng $\mathrm{KW}$, Russell S. Designing and building oncolytic viruses. Future Virol. 2017;12(4):193-213.

26. Selman M, Ou P, Rousso C, Bergeron A, Krishnan R, Pikor $\mathrm{L}$, et al. Dimethyl fumarate potentiates oncolytic virotherapy through NF-kappaB inhibition. Sci Transl Med. 2018;10(425):eaao1613.

27. Jennings VA, Scott GB, Rose AMS, Scott KJ, Migneco G, Keller B, et al. Potentiating oncolytic virus-induced immunemediated tumor cell killing using histone deacetylase inhibition. Mol Ther. 2019;27(6):1139-52.

28. Jaime-Ramirez AC, Yu JG, Caserta E, Yoo JY, Zhang J, Lee $\mathrm{TJ}$, et al. Reolysin and histone deacetylase inhibition in the treatment of head and neck squamous cell carcinoma. Mol Ther Oncolytics. 2017;16(5):87-96.

29. Bridle BW, Chen L, Lemay CG, Diallo JS, Pol J, Nguyen $A$, et al. HDAC inhibition suppresses primary immune responses, enhances secondary immune responses, and abrogates autoimmunity during tumor immunotherapy. Mol Ther. 2013;21(4):887-94.

30. Wongthida P, Diaz RM, Pulido C, Rommelfanger D, Galivo F, Kaluza K, et al. Activating systemic T-cell immunity against self tumor antigens to support oncolytic virotherapy with vesicular stomatitis virus. Human Gene Ther. 2011;22:1343-53.

31. Barber GN. STING: infection, inflammation and cancer. Nat Rev Immunol. 2015;15(12):760-70.

32. Xia T, Konno H, Barber GN. Recurrent loss of STING signaling in melanoma correlates with susceptibility to viral oncolysis. Cancer Res. 2016;76(22):6747-59.

33. de Queiroz N, Xia T, Konno H, Barber GN. Ovarian cancer cells commonly exhibit defective STING signaling which affects sensitivity to viral oncolysis. Mol Cancer Res. 2019;17(4):974-86.

34. Galluzzi L, Vitale I, Aaronson SA, Abrams JM, Adam D, Agostinis $\mathrm{P}$, et al. Molecular mechanisms of cell death: recommendations of the Nomenclature Committee on Cell Death 2018. Cell Death Differ. 2018;25(3):486-541.

35. Galluzzi L, Buque A, Kepp O, Zitvogel L, Kroemer G. Immunogenic cell death in cancer and infectious disease. Nat Rev Immunol. 2017;17(2):97-111.

36. Donnelly OG, Errington-Mais F, Steele L, Hadac E, Jennings V, Scott K, et al. Measles virus causes immunogenic cell death in human melanoma. Gene Ther. 2013;20(1):7-15.

37. Gauvrit A, Brandler S, Sapede-Peroz C, Boisgerault N, Tangy F, Gregoire M. Measles virus induces oncolysis of mesothelioma cells and allows dendritic cells to cross-prime tumor-specific CD8 response. Cancer Res. 2008;68(12):4882-92.

38. Moehler MH, Zeidler M, Wilsberg V, Cornelis JJ, Woelfel T, Rommelaere J, et al. Parvovirus H-1-induced tumor cell death enhances human immune response in vitro via increased phagocytosis, maturation, and cross-presentation by dendritic cells. Hum Gene Ther. 2005;16(8):996-1005.

39. Prestwich RJ, Errington F, Ilett EJ, Morgan RS, Scott KJ, Kottke $\mathrm{T}$, et al. Tumor infection by oncolytic reovirus primes adaptive anti tumor immunity. Clin Cancer Res. 2008;14:7358-66. 
40. Galanis E, Atherton PJ, Maurer MJ, Knutson KL, Dowdy SC, Cliby WA, et al. Oncolytic measles virus expressing the sodium iodide symporter to treat drug-resistant ovarian cancer. Cancer Res. 2015;75(1):22-30.

41. Krabbe T, Altomonte J. Fusogenic viruses in oncolytic immunotherapy. Cancers (Basel). 2018;10(7):E216.

42. Spranger S, Dai D, Horton B, Gajewski TF. Tumor-residing Batf3 dendritic cells are required for effector $\mathrm{T}$ cell trafficking and adoptive T cell therapy. Cancer Cell. 2017;31(5):711-23.e4.

43. Bottcher JP, Reis ESC. The role of type 1 conventional dendritic cells in cancer immunity. Trends Cancer. 2018;4(11):784-92.

44. Bottcher JP, Bonavita E, Chakravarty P, Blees H, Cabeza-Cabrerizo $M$, Sammicheli $S$, et al. NK cells stimulate recruitment of $\mathrm{CDC} 1$ into the tumor microenvironment promoting cancer immune control. Cell. 2018;172(5):1022-37.e14.

45. Sanchez-Paulete AR, Teijeira A, Quetglas JI, Rodriguez-Ruiz ME, Sanchez-Arraez A, Labiano S, et al. Intratumoral immunotherapy with XCL1 and sFlt3L encoded in recombinant Semliki Forest Virus-derived vectors fosters dendritic cell-mediated T-cell cross-priming. Cancer Res. 2018;78(23):6643-54.

46. Freedman JD, Hagel J, Scott EM, Psallidas I, Gupta A, Spiers L, et al. Oncolytic adenovirus expressing bispecific antibody targets T-cell cytotoxicity in cancer biopsies. EMBO Mol Med. 2017;9(8):1067-87.

47. Yu F, Wang X, Guo ZS, Bartlett DL, Gottschalk SM, Song XT. T-cell engager-armed oncolytic vaccinia virus significantly enhances antitumor therapy. Mol Ther. 2014;22(1):102-11.

48. Freedman JD, Duffy MR, Lei-Rossmann J, Muntzer A, Scott EM, Hagel J, et al. An oncolytic virus expressing a T-cell engager simultaneously targets cancer and immunosuppressive stromal cells. Cancer Res. 2018;78(24):6852-65.

49. de Sostoa J, Fajardo CA, Moreno R, Ramos MD, Farrera-Sal M, Alemany R. Targeting the tumor stroma with an oncolytic adenovirus secreting a fibroblast activation protein-targeted bispecific T-cell engager. J Immunother Cancer. 2019;7(1):19.

50. Diaz RM, Galivo F, Kottke T, Wongthida P, Qiao J, Thompson J, et al. Oncolytic immunovirotherapy for melanoma using vesicular stomatitis virus. Cancer Res. 2007;67:2840-8.

51. Pulido J, Kottke T, Thompson J, Galivo F, Wongthida P, Diaz $\mathrm{RM}$, et al. Using virally expressed melanoma cDNA libraries to identify tumor-associated antigens that cure melanoma. Nat Biotechnol. 2012;30(4):337-43.

52. Suksanpaisan L, Xu R, Tesfay MZ, Bomidi C, Hamm S, Vandergaast R, et al. Preclinical development of oncolytic immunovirotherapy for treatment of HPV(POS) cancers. Mol Ther Oncolytics. 2018;28(10):1-13.

53. Bridle BW, Stephenson KB, Boudreau JE, Koshy S, Kazdhan N, Pullenayegum E, et al. Potentiating cancer immunotherapy using an oncolytic virus. Mol Ther. 2010;18:1430-9.

54. Tysome JR, Li X, Wang S, Wang P, Gao D, Du P, et al. A novel therapeutic regimen to eradicate established solid tumors with an effective induction of tumor-specific immunity. Clin Can Res. 2012;18(24):6679-89.

55. Atherton MJ, Stephenson KB, Pol J, Wang F, Lefebvre C, Stojdl DF, et al. Customized viral immunotherapy for HPV-associated cancer. Cancer Immunol Res. 2017;5(10):847-59.

56. Wei SC, Duffy CR, Allison JP. Fundamental mechanisms of immune checkpoint blockade therapy. Cancer Disc. 2018;8(9):1069-86.

57. Pardoll DM. The blockade of immune checkpoints in cancer immunotherapy. Nat Rev Cancer. 2012;12(4):252-64.

58. Sharpe AH, Pauken KE. The diverse functions of the PD1 inhibitory pathway. Nat Rev Immunol. 2018;18(3):153-67.

59. Topalian SL, Hodi FS, Brahmer JR, Gettinger SN, Smith DC, McDermott DF, et al. Safety, activity, and immune correlates of anti-PD-1 antibody in cancer. N Engl J Med. 2012;366(26):2443-54.

60. Yarchoan M, Hopkins A, Jaffee EM. Tumor mutational burden and response rate to PD-1 inhibition. N Engl J Med. 2017;377(25):2500-1.

61. Ji RR, Chasalow SD, Wang L, Hamid O, Schmidt H, Cogswell $\mathrm{J}$, et al. An immune-active tumor microenvironment favors clinical response to ipilimumab. Cancer Immunol Immunother. 2012;61(7):1019-31.

62. Chen DS, Mellman I. Elements of cancer immunity and the cancer-immune set point. Nature. 2017;541(7637):321-30.

63. De Henau O, Rausch M, Winkler D, Campesato LF, Liu C, Cymerman DH, et al. Overcoming resistance to checkpoint blockade therapy by targeting PI3Kgamma in myeloid cells. Nature. 2016;539(7629):443-7.

64. Zamarin D, Holmgaard RB, Subudhi SK, Park JS, Mansour M, Palese P, et al. Localized oncolytic virotherapy overcomes systemic tumor resistance to immune checkpoint blockade immunotherapy. Sci Transl Med. 2014;6(226):226ra32.

65. Woller N, Gurlevik E, Fleischmann-Mundt B, Schumacher A, Knocke S, Kloos AM, et al. Viral infection of tumors overcomes resistance to $\mathrm{PD}$-1-immunotherapy by broadening neoantigenome-directed T-cell responses. Mol Ther. 2015;23(10):1630-40.

66. Cockle JV, Rajani K, Zaidi S, Kottke T, Thompson J, Diaz RM, et al. Combination viroimmunotherapy with checkpoint inhibition to treat glioma, based on location-specific tumor profiling. Neuro Oncol. 2016;18(4):518-27.

67. Sivanandam V, LaRocca CJ, Chen NG, Fong Y, Warner SG. Oncolytic viruses and immune checkpoint inhibition: the best of both worlds. Mol Ther Oncolytics. 2019;28(13):93-106.

68. Shen W, Patnaik MM, Ruiz A, Russell SJ, Peng KW. Immunovirotherapy with vesicular stomatitis virus and PD-L1 blockade enhances therapeutic outcome in murine acute myeloid leukemia. Blood. 2016;127(11):1449-58.

69. Liu Z, Ge Y, Wang H, Ma C, Feist M, Ju S, et al. Modifying the cancer-immune set point using vaccinia virus expressing redesigned interleukin-2. Nat Commun. 2018;9(1):4682.

70. Saha D, Martuza RL, Rabkin SD. Oncolytic herpes simplex virus immunovirotherapy in combination with immune checkpoint blockade to treat glioblastoma. Immunotherapy. 2018;10(9):779-86.

71. Bourgeois-Daigneault MC, Roy DG, Aitken AS, El Sayes N, Martin NT, Varette O, et al. Neoadjuvant oncolytic virotherapy before surgery sensitizes triple-negative breast cancer to immune checkpoint therapy. Sci Transl Med. 2018;10(422):eaao1641.

72. Bommareddy PK, Aspromonte S, Zloza A, Rabkin SD, Kaufman HL. MEK inhibition enhances oncolytic virus immunotherapy through increased tumor cell killing and $\mathrm{T}$ cell activation. Sci Transl Med. 2018;10(471):eaau0417.

73. Shim KG, Zaidi S, Thompson J, Kottke T, Evgin L, Rajani KR, et al. Inhibitory receptors induced by VSV viroimmunotherapy are not necessarily targets for improving treatment efficacy. Mol Ther. 2017;25(4):962-75.

74. Nakashima H, Alayo QA, Penaloza-MacMaster P, Freeman GJ, Kuchroo VK, Reardon DA, et al. Modeling tumor immunity of mouse glioblastoma by exhausted CD8(+) T cells. Sci Rep. 2018;8(1):208.

75. Rojas JJ, Sampath P, Hou W, Thorne SH. Defining effective combinations of immune checkpoint blockade and oncolytic virotherapy. Clin Cancer Res. 2015;21(24):5543-51.

76. Fend L, Yamazaki T, Remy C, Fahrner C, Gantzer M, Nourtier V, et al. Immune checkpoint blockade, immunogenic chemotherapy or IFN-alpha blockade boost the local and abscopal effects of oncolytic virotherapy. Cancer Res. 2017;77(15):4146-57. 
77. Gao Y, Whitaker-Dowling P, Griffin JA, Barmada MA, Bergman I. Recombinant vesicular stomatitis virus targeted to Her2/ neu combined with anti-CTLA4 antibody eliminates implanted mammary tumors. Cancer Gene Ther. 2009;16(1):44-52.

78. Rajani K, Parrish C, Kottke T, Thompson J, Zaidi S, Ilett L, et al. Combination therapy with reovirus and anti-PD-1 blockade controls tumor growth through innate and adaptive immune responses. Mol Ther. 2016;24(1):166-74.

79. Ribas A, Dummer R, Puzanov I, VanderWalde A, Andtbacka RHI, Michielin O, et al. Oncolytic virotherapy promotes intratumoral $\mathrm{T}$ cell infiltration and improves anti-PD-1 immunotherapy. Cell. 2017;170(6):1109-19.e10.

80. Engeland CE, Grossardt C, Veinalde R, Bossow S, Lutz D, Kaufmann JK, et al. CTLA-4 and PD-L1 checkpoint blockade enhances oncolytic measles virus therapy. Mol Ther. 2014;22(11):1949-59.

81. Passaro C, Alayo Q, De Laura I, McNulty J, Grauwet K, Ito H, et al. Arming an oncolytic herpes simplex virus type 1 with a single-chain fragment variable antibody against PD-1 for experimental glioblastoma therapy. Clin Can Res. 2019;25(1):290-9.

82. Rosewell Shaw A, Porter CE, Watanabe N, Tanoue K, Sikora A, Gottschalk S, et al. Adenovirotherapy delivering cytokine and checkpoint inhibitor augments CAR T cells against metastatic head and neck cancer. Mol Ther. 2017;25(11):2440-51.

83. Curti B, Richards J, Faries M, Grose M, Karpathy R, Shafren DR. Phase Ib study of a novel immunotherapy combination therapy of intralesional coxsackievirus A21 and systemic ipilimumab in patients with advanced melanoma [abstract no. CT021]. Cancer Res. 2016;76 (14 Suppl.):CT021.

84. Silk AW, Kaufman H, Gabrail N, Mehnert J, Bryan J, Norrell $\mathrm{J}$, et al. Phase $1 \mathrm{~b}$ study of intratumoral Coxsackievirus A21 (CVA21) and systemic pembrolizumab in advanced melanoma patients: Interim results of the CAPRA clinical trial [abstract no. CT026]. Cancer Res. 2017;77(13 Suppl.):CT026.

85. Kamphorst AO, Wieland A, Nasti T, Yang S, Zhang R, Barber DL, et al. Rescue of exhausted CD8 T cells by PD-1-targeted therapies is CD28-dependent. Science. 2017;355(6332):1423-7.

86. Ma HS, Poudel B, Torres ER, Sidhom JW, Robinson TM, Christmas B, et al. A CD40 agonist and PD-1 antagonist antibody reprogram the microenvironment of nonimmunogenic tumors to allow T-cell-mediated anticancer activity. Cancer Immunol Res. 2019;7(3):428-42.

87. Foote JB, Kok M, Leatherman JM, Armstrong TD, Marcinkowski BC, Ojalvo LS, et al. A STING agonist given with OX40 receptor and PD-L1 modulators primes immunity and reduces tumor growth in tolerized mice. Cancer Immunol Res. 2017;5(6):468-79.

88. Hebb JPO, Mosley AR, Vences-Catalan F, Rajasekaran N, Rosen A, Ellmark P, et al. Administration of low-dose combination antiCTLA4, anti-CD137, and anti-OX40 into murine tumor or proximal to the tumor draining lymph node induces systemic tumor regression. Cancer Immunol Immunother. 2018;67(1):47-60.

89. Rosenberg SA, Packard BS, Aebersold PM, et al. Use of tumorinfiltrating lymphocytes and interleukin-2 in the immunotherapy of patients with metastatic melanoma, special report. N Engl J Med. 1988;319:1676-80.

90. Muul LM, Spiess PJ, Director EP, Rosenberg SA. Identification of specific cytolytic immune responses against autologous tumor in humans bearing malignant melanoma. J Immunol. 1987;138(3):989-95.

91. Rosenberg SA, Yannelli JR, Yang JC, Topalian SL, Schwartzentruber DJ, Weber JS, et al. Treatment of patients with metastatic melanoma with autologous tumor-infiltrating lymphocytes and interleukin 2. J Natl Cancer Inst. 1994;86(15):1159-66.

92. Gattinoni L, Finkelstein SE, Klebanoff CA, Antony PA, Palmer DC, Spiess PJ, et al. Removal of homeostatic cytokine sinks by lymphodepletion enhances the efficacy of adoptively transferred tumor-specific CD8+T cells. J Exp Med. 2005;202(7):907-12.

93. Besser MJ, Shapira-Frommer R, Treves AJ, Zippel D, Itzhaki $\mathrm{O}$, Hershkovitz L, et al. Clinical responses in a phase II study using adoptive transfer of short-term cultured tumor infiltration lymphocytes in metastatic melanoma patients. Clin Can Res. 2010;16(9):2646-55.

94. Baruch EN, Berg AL, Besser MJ, Schachter J, Markel G. Adoptive $\mathrm{T}$ cell therapy: an overview of obstacles and opportunities. Cancer. 2017;123(S11):2154-62.

95. Brentjens RJ, Davila ML, Riviere I, Park J, Wang X, Cowell LG, et al. CD19-targeted T cells rapidly induce molecular remissions in adults with chemotherapy-refractory acute lymphoblastic leukemia. Sci Transl Med. 2013;5(177):177ra38.

96. Castellarin M, Watanabe K, June CH, Kloss CC, Posey AD Jr. Driving cars to the clinic for solid tumors. Gene Ther. 2018;25(3):165-75.

97. Rosewell Shaw A, Suzuki M. Oncolytic viruses partner with T-cell therapy for solid tumor treatment. Front Immunol. 2018;9:2103

98. Watanabe K, Luo Y, Da T, Guedan S, Ruella M, Scholler J, et al. Pancreatic cancer therapy with combined mesothelin-redirected chimeric antigen receptor $\mathrm{T}$ cells and cytokine-armed oncolytic adenoviruses. JCI Insight. 2018. https://doi.org/10.1172/jci.insig ht.99573.

99. Rommelfanger DM, Wongthida P, Diaz RM, Kaluza KM, Thompson JM, Kottke TJ, et al. Systemic combination virotherapy for melanoma with tumor antigen-expressing vesicular stomatitis virus and adoptive T-cell transfer. Cancer Res. 2012;72(18):4753-64.

100. Walsh SR, Bastin D, Chen L, Nguyen A, Storbeck CJ, Lefebvre $\mathrm{C}$, et al. Type I IFN blockade uncouples immunotherapy-induced antitumor immunity and autoimmune toxicity. J Clin Invest. 2019;129(2):518-30.

101. Sabatino M, Hu J, Sommariva M, Gautam S, Fellowes V, Hocker JD, et al. Generation of clinical-grade CD19-specific CAR-modified CD8 + memory stem cells for the treatment of human B-cell malignancies. Blood. 2016;128(4):519-28.

102. Klebanoff CA, Gattinoni L, Restifo NP. Sorting through subsets: which T-cell populations mediate highly effective adoptive immunotherapy? J Immunother. 2012;35(9):651-60.

103. Achard C, Surendran A, Wedge ME, Ungerechts G, Bell J, Ilkow CS. Lighting a fire in the tumor microenvironment using oncolytic immunotherapy. EBioMedicine. 2018;31:17-24.

104. LaRocca CJ, Warner SG. Oncolytic viruses and checkpoint inhibitors: combination therapy in clinical trials. Clin Transl Med. 2018;7(1):35.

105. Speranza MC, Passaro C, Ricklefs F, Kasai K, Klein SR, Nakashima $\mathrm{H}$, et al. Preclinical investigation of combined genemediated cytotoxic immunotherapy and immune checkpoint blockade in glioblastoma. Neuro Oncol. 2018;20(2):225-35.

106. Cervera-Carrascon V, Siurala M, Santos JM, Havunen R, Tahtinen S, Karell P, et al. TNFa and IL-2 armed adenoviruses enable complete responses by anti-PD-1 checkpoint blockade. Oncoimmunology. 2018;7(5):e1412902.

107. Kuryk L, Moller AW, Jaderberg M. Combination of immunogenic oncolytic adenovirus ONCOS-102 with anti-PD-1 pembrolizumab exhibits synergistic antitumor effect in humanized A2058 melanoma huNOG mouse model. Oncoimmunology. 2019;8(2):e1532763.

108. Saha D, Martuza RL, Rabkin SD. Macrophage polarization contributes to glioblastoma eradication by combination immunovirotherapy and immune checkpoint blockade. Cancer Cell. 2017;32(2):253-67 e5.

109. Chen CY, Wang PY, Hutzen B, Sprague L, Swain HM, Love $\mathrm{JK}$, et al. Cooperation of oncolytic herpes virotherapy and 
PD-1 blockade in murine rhabdomyosarcoma models. Sci Rep. 2017;7(1):2396.

110. Zamarin D, Ricca JM, Sadekova S, Oseledchyk A, Yu Y, Blumenschein WM, et al. PD-L1 in tumor microenvironment mediates resistance to oncolytic immunotherapy. J Clin Invest. 2018;128(11):5184.

111. Kelly KR, Espitia CM, Zhao W, Wu K, Visconte V, Anwer F, et al. Oncolytic reovirus sensitizes multiple myeloma cells to anti-PD-L1 therapy. Leukemia. 2018;32(1):230-3.
112. Kowalsky SJ, Liu Z, Feist M, Berkey SE, Ma C, Ravindranathan $\mathrm{R}$, et al. Superagonist IL-15-armed oncolytic virus elicits potent antitumor immunity and therapy that are enhanced with PD-1 blockade. Mol Ther. 2018;26(10):2476-86. 